\title{
Effect of Tea Tree Oil on Improvement of Hair Damage
}

Ju-Sub Kim

Department of Beauty Design, Sangji University, Wonju-si, Gangwon-do, Korea

Corresponding author: Ju-Sub Kim, Department of Beauty Design, Sangji University, 84 Sangjidae-gil, Wonju-si, Gangwondo 26339, Korea

Tel.: +82 337300811

Fax: +82337300811

Email: c-miro@hanmail.net

Received June 25, 2021

Revised July 21, 2021

Accepted August 5, 2021

Published September 30, 2021

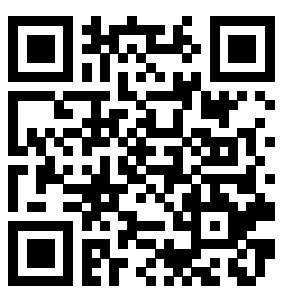

\begin{abstract}
Purpose: The study aimed to investigate the effects of tea tree oil on damaged hair. Methods: A texture-improving agent was produced by adding different dosages of tea tree oil (i.e., 0, 2, 4, and 6 g) on sample hair. Comparative analysis was conducted by measuring the effects of the agent before and after application to sample hair bleached into level 8 . To examine changes in hair brightness, $L^{*}$ value was measured using a color difference meter. In addition, to determine the effects of the agent on damaged hair, the study measured tensile strength, absorbance using methylene blue, and hair gloss. Results: The mean $L^{*}$ value for each sample increased for healthy hair but decreased in the $8 \mathrm{~L}$ samples. Analysis indicates that the healthy hair, $8 \mathrm{~L}(4)$ sample, and $8 \mathrm{~L}(6)$ samples pointed to significant results. The mean value for tensile strength increased for all healthy and $8 \mathrm{~L}$ hair samples after application. Specifically, the $8 \mathrm{~L}(4)$ and $8 \mathrm{~L}(6)$ samples displayed significant results. In terms of absorbance, the mean value decreased for all healthy and $8 \mathrm{~L}$ hair samples after application. Moreover, hair gloss values increased for samples applied with the agent containing tea tree oil. Specifically, the $8 \mathrm{~L}(2), 8 \mathrm{~L}(4)$, and $8 \mathrm{~L}(6)$ samples exhibited increased values after application. Conclusions: The results confirm the effects of tea tree oil on damaged hair in terms of improvements in terms of tensile strength, absorbance, and gloss. The study recommends that further research on the effects of various oils and natural extracts on damaged hair is necessary in terms of improving other hair characteristics and using more samples.
\end{abstract}

Keywords: Tea tree oil, Hair, Improvement, Hair texture, Damage

\section{Introduction}

인간의 모발은 외모를 대표하는 가장 큰 특징 중 하나로서 개인의 성향이나 취향에 따라 다양한 방법으로 모발에 변화를 주고 이틀 통 해 개성을 표현하고 있다(Lim et al., 2020). 헤어스타일의 다양화를 위한 헤어스타일링 방법과 사용되는 스타일링기구의 발전으로 편리 성은 좋아졌지만 기구의 남용으로 모발 손상이 쉽게 이루어진다(Kim \& Cheong, 2018). 염색은 퍼머와 같이 인체에 화학약품을 사용하는 것으로 모발 염색 후 퇴색이 되거나 반복 시술에 의한 모발 손상과 물 빠짐 같은 부작용과 문제점이 나타나고 있다(Park et al., 2019). 손 상된 모발은 빗질 시 엉킴 현상이 일어나고, 유분, 수분의 감소로 인 해 모발이 거칠고 메말라 보인다(Kim et al., 2010a). 모표피는 모 발을 보호하고 광택, 탄성과 밀접한 관계가 있고, 모피질은 강도와 탄성과 관계가 있다. 모발이 손상되면 모피질의 공동현상으로 흡수 력이 높아지고, 모발의 화학 구조의 이상으로 인장강도가 떨어진다
(Kim et al., 2010b). 이렇게 모발은 물리, 화학적 부작용으로 모발 이 거칠어지고 끊어짐이 일어난다(Min et al., 2011). 이에 미용 산 업도 미와 건강에 관련한 제품으로 모발 보호의 대안을 제시하고 있 는 추세이다(La et al., 2013). 손상된 모발의 질 개선을 위한 방법 으로는 염색, 퍼머제 도포 처리 시 차별화, 다양화에 의한 모질 개선 방법과, 모발 트리트먼트제 도포 등의 제품에 의한 개선 방안이 있 다. 모발에 화학적 성분이 함유된 제품으로 모질 개선 방법 연구로 는 알칼리성 모발처리제를 이용한 후 처리제 개발(Kim, 2017), 칼라 링 처리에 의한 모발의 형태학적 변화(Jang \& Choi, 2001), 모발의 화학적 처리에 의한 손상도 측정 및 기계적 특성에 대한 연구(Song et al., 2006) 등이 있고, 모발의 질 개선을 위한 성분 연구로는 서리 태 발효 주출물이 탈색을 통해 손상된 모발에 미치는 영향(Jung et al., 2017), 천연 추출물의 손상 모발 개선 효과에 관한 연구(Kim \& Han, 2013), 동충하초 추출물에 의한 모발의 화학적·물리적 개선효 과(Kim, 2013), 땅콩오일의 모질개선효과(Kim, 2020a), 자색고구마 
의 염색효과와 모질 개선효과 연구(Kim, 2020b)등으로 연구가 이루 어 지고 있다. 추출물에 의한 연구가 이루어지고 있지만 아직도 부족 한 실정이다. 이에 티트리(tea tree) 오일을 이용하여 손상된 모발에 개선 효과가 있는지를 알고자 하였다. 티트리는 촉진력과 강장 효능 이 있으며 살균력이 매우 강하고, 여드름 치료에 폭넓게 활용되고 있 고 비듬치유효과가 있어 지성비듬, 염증두피에 사용한다(Kim et al., 2017). 티트리 관련 선행 연구로는 티트리 및 팔마로사 에션셜 오일 의 여드름 피부에 미치는 효과(Kim et al., 2013), 티트리 에센셜 오 일의 항산화 활성 및 피부 주름개선효과(Bae, 2020)등 피부분야에서 연구가 이루어졌다. 이러한 티트리 오일을 모발에 적용 연구하고자 하였다.

따라서 본 연구는 티트리 오일이 손상된 모발을 개선 하는데 성분 으로 사용 가능 한지를 알아보고자 하였다. 실험을 위해 티트리 오일 을 함량 별로 다르게 하여 도포력 향상을 위해 펌제이스제에 혼합하 여 제형제를 제조하였다. 제형제로 모발에 도포 전, 후를 비교 분석 하였다. 비교 분석은 티트리 오일에 의해 모발의 명도 변화를 알아보 고자 색차계 측정을 하였고, 또한 모발의 인장강도, 메틸렌블루를 이 용한 흡광도 측정, 모표면 광택을 측정하여 손상된 모발의 개선 정도 를 알아보고자 하였다.

\section{Methods}

\section{1. 실험재료}

1) 시료 모발

실험에 사용된 모발은 최근 2 년 동안 약물복용과 화학적 시술을 하지 않은 18 세 여성의 모발을 후두부에서 두피 $3 \mathrm{~cm}$ 지점을 기준 으로 $20 \mathrm{~cm}$ 로 채취하여 $2 \mathrm{~g}$ 씩 모(hair) 다발을 만들었다. 플레인 린 스 후 자연건조하여 사용하였다. 티트리 오일의 모발 손상 개선 정도
를 연구하기 위하여 화학적시술을 전혀 하지 않은 건강모와 건강 모 발에 탈색제 제1제(ammonium persulfate, potassium persulfate, sodium metasilicate, magnesium, sodium carboxymethyl cellulose) (Suanhj, Korea) $3 \mathrm{mg}$ 과 제 2 제(6\%의 과산화수소를 주성 분으로 water, etidronic acid, phosphoric acid, sodium phosphate dibasic, cetyl alcohol로 구성된 제품) (Suanhj, Korea) $3 \mathrm{~mL}$ 를 1:1 비율로 혼합, 도포하고 $30 \mathrm{~min}$ 방치 후 세척하여 명도 8레벨 시료 4 다발을 제작하였다. 실험에 사용된 모발 시료의 level 측정기(level scale, Wella, Germany)사용하여 측정하였다. 모발 시료에 티트리 오일로 제조된 제형제로 도포 전과 후를 비교하였다.

\section{2) 티트리 오일}

실험에 사용 한 티트리 오일은 Environmental Working Group (EWG) 그린 등급의 화장품원료로 사용되는 오일로 코리아싸밀락 (Korea Similac, Walterenterprise Co., Lt, Korea)에서 구입하여 사 용하였다.

\section{3) 모질 개선 제형제 제조}

실험에 사용한 모질 개선 제형제의 펌베이스제는 (주)수안향장 (Korea)에서 제조한 것으로 모든 제조에 사용하였으며, 펌베이스제 조성표는 Table 1과 같다. 이 펌 베이스제에 티트리 오일 $0 \mathrm{~g}, 2 \mathrm{~g}, 4$ $\mathrm{g}, 6 \mathrm{~g}$ 함량을 다르게 하여 혼합 제조였다.

\section{4) 측정기기 및 측정방법}

(1) 도포 전, 후의 명도 $\left(\mathrm{L}^{*}\right)$ 변화 측정

함량 별로 티트리 오일이 함유된 모발 개선 제형제로 도포 전과 후 의 표면 색상 변화를 알아보고자 색차계(Color meter, CS-10; CHN spec, China)를 이용하여 CIELAB 표색계의 색상 값인 명도지수 $\mathrm{L}^{*}$ 값을 측정하였다.

Table 1. Composition of perm-base agent

\begin{tabular}{|c|c|c|c|c|}
\hline No & Ingredients & Content (\%) & Content (kg) & Function \\
\hline 1 & Water & 89.85 & 89.85 & Solvent \\
\hline 2 & Tri ethanolamine & 0.15 & 0.15 & pH adjuster \\
\hline \multirow{2}{*}{3} & Cetyl alcohol & \multirow{2}{*}{3.00} & 1.80 & Emulsion stabilizer \\
\hline & Ceteth-40 & & 1.20 & Surfactant \\
\hline \multirow{4}{*}{4} & Myristyl alcohol & \multirow{4}{*}{2.00} & 0.04 & Emulsion stabilizer \\
\hline & Cetyl alcohol & & 0.22 & Emulsion stabilizer \\
\hline & Stearyl alcohol & & 1.72 & Emulsion stabilizer \\
\hline & Arachidyl alcohol & & 0.02 & Emulsion stabilizer \\
\hline \multirow{3}{*}{5} & Stearic acid & & 0.44 & Surfactant \\
\hline & Palmitic acid & 1.00 & 0.55 & Surfactant \\
\hline & Myristic acid & & 0.01 & Surfactant \\
\hline 6 & Mineral oil & 4.00 & 4.00 & Conditioning agent \\
\hline
\end{tabular}


측정값의 신뢰성을 높이기 위해 12 회 측정하여 최고 값과 최저 값 을 제외한 10 회의 측정 값으로 비교 분석하였다.

\section{(2) 인장강도 측정}

모발 시료에 도포하기 전과 후의 인장강도를 측정하였다. 측정 기 기(Digital force gauge, HF-20; Tripod, China)로 인장강도를 측정 하였다. 측정값의 신뢰성을 위하여 7회 측정 후 측정 값 중 최고 값과 최저 값을 제외한 5 회의 측정 값으로 비교 분석하였다.

\section{(3) 메틸렌블루를 이용한 흡광도 측정}

메틸렌블루(Methylene blue)를 이용하여 모발 시료에 도포하 기 전과 후의 흡광도를 측정하였다. 모발의 외경은 마이크로미터 (Quickmike, Mitutoyo)를 이용하여 0.075-0.080 mm의 굵기 오차 범위를 정하고 $4 \mathrm{~cm}$ 의 길이로 2 가닥 잘랐다. 자른 후 2 가닥의 모발을 tube에 넣은 후 $\mathrm{MB}$ solution에 담가 vortex mixer (Vortex genie 2, Scientific Industries, USA)를 이용하여 $10 \mathrm{~s}$ 동안 vortexing하였다. $50^{\circ} \mathrm{C}$ heat block (wise therm HB-48P; Daihan Scientific, Korea) 에서 $10 \mathrm{~min}$ 간 유지하여 $\mathrm{MB}$ solution을 흡착시키고, tube에 있는 2 가닥의 시료를 꺼내어 표면에 묻어있는 MB solution은 실험용 티슈를 이용하여 제거하고, 시료 2 가닥을 각각 새 tube에 옮겨 담았다. 이 tube에 NR desorb solution을 $5 \mathrm{~mL}$ 를 넣고 상온에서 $5 \mathrm{~min}$ 방치 후 $10 \mathrm{~s}$ vortexing 후 추출하였다. 추출한 용액을 큐벳(cuvettes)에 3000 $\mu \mathrm{L}$ 분주하여 $\mathrm{MB}$ 의 흡수 강도가 가장 높은 파장인 $660 \mathrm{~nm}$ 로 흡광 도를 측정하였다. 1 회 추출 후 같은 방법으로 총 2 회 분광광도계(Vis spectrophotometer, SV1200; Azzota, USA)로 흡광도를 측정 총 4 회의 값으로 비교 분석하였다. 측정 시 기준 값을 잡기 위해 desorb solution을 $3000 \mu \mathrm{L}$ 분주하여 blank를 만들어준다. $\mathrm{MB}$ 시약은 $\mathrm{DW}$ $20 \mathrm{~mL}+\mathrm{MB} 400 \mu \mathrm{L}$ 으로 희석하여 $2 \%$ 로 만들어 사용하였다. NR solution은 $49 \%$ ethanol $(49 \mathrm{~mL})+1 \%$ glacial aceticacid $(1 \mathrm{~mL})+$ $50 \% \mathrm{DW}(50 \mathrm{~mL})$ 의 비율로 완성하였다.

\section{(4) 모발 표면 광택 측정}

모발 시료에 도포하기 전과 후의 광택 변화를 알아보고자 광택계 (Gloss meter NHG268; Shenzhen Threenh Technology, China)를 이용하여 측정하였다. 측정값의 신뢰성을 높이기 위해 12 회 측정하여 최고 값과 최저 값을 제외한 10 회의 측정 값으로 비교 분석하였다.
5) 도포 실험방법

도포 전 측정은 건강모 $(3 \mathrm{~g})$ 와 탈색으로 시술 한 모발 시료 8레벨 시료 전체 다발 $(12 \mathrm{~g})$ 을 가지고 명도, 인장강도, 흡광도, 광택을 측정 하였고, 도포 후 측정은 건강모에 티트리 오일 $4 \mathrm{~g}$ 도포, 8레벨 시료 에는 티트리 오일을 $0 \mathrm{~g}, 2 \mathrm{~g}, 4 \mathrm{~g}, 6 \mathrm{~g}$ 첨가한 제형제로 각각의 시료 에 $20 \mathrm{~g}$ 도포 후에 측정하였다. 도포한 후 열처리 $10 \mathrm{~min}$ 과 자연건 조 $20 \mathrm{~min}$ 후에 세척하여 자연건조 시켜 측정하였다. 시료에 도포는 도포량, 자연방치시간, 열처리 시간, 시술자의 숙련도에 등에 따라서 측정에 차이가 있을 수 있기 때문에 최대한 차이를 줄이기 위해 시 술자는 각 단계별로 동일인이 시술하였다. 각 티트리 오일의 함량에 따른 모질 개선 제형제 시료 표기는 Table 2 와 같다. Virgin hair는 건강모 시료에 티트리 오일 $0 \mathrm{~g}$ 과 펌베이스 $20 \mathrm{~g}$ 혼합 도포, $8 \mathrm{~L}(0)$ 시료는 8레벨시료에 티트리 오일 $0 \mathrm{~g}$ 과 펌베이스 $20 \mathrm{~g}$ 혼합 도포, 8L(2) 시료는 8레벨시료에 티트리 오일 $2 \mathrm{~g}$ 과 펌베이스 $18 \mathrm{~g}$ 혼합 도포, 8L(4) 시료는 8레벨시료에 티트리 오일 $4 \mathrm{~g}$ 과 펌베이스 $16 \mathrm{~g}$ 혼합 도포, 8L(6) 시료는 8레벨시료에 티트리 오일 $6 \mathrm{~g}$ 과 펌베이스 $14 \mathrm{~g}$ 혼합 도포하였다.

\section{6) 결과 분석}

각 항목의 실험은 명도측정과 광택측정은 10 회, 인장강도는 5 회 측정, 흡광도는 4 회 측정한 값으로 도포 전과 후를 비교하였다. 신 뢰성과 객관성을 높이기 위한 통계분석을 위해 평균(mean), 표준편 차(standard division, $\mathrm{SD}$ )를 구하고 사후 검증으로 통계 프로그램인 jamovi 1.2.27 solid를 이용하여 $t$-tests(Paired sample t-test)로 양측검정(two tailed test)실시하였고, 유의 수준은 $p<0.05$ 수준에서 검증하였다. 귀무가설은 "도포 전과 후의 차이가 없다" 이고 연구가 설은 "도포 전과 후의 차이가 있다"로 하였다.

\section{Results and Discussion}

\section{1. 시료 별 명도 변화 측정}

시료 별 도포 전과 도포 후 $\mathrm{L}^{*}$ 값 측정 결과는 Table 3 과 같다. $\mathrm{L}^{*}$ 은 밝기인 명도(lightness)를 표현하는 수치로 0에서 100사이의 수치로 표시한다. 이때 0 은 black을 나타내고, 100 은 white를 나타낸다. 티 트리 오일을 함유한 개선 제형제로 도포한 모발의 $\mathrm{L}^{*}$ 값의 평균은 도

\section{Table 2. Expression method for samples}

\begin{tabular}{ll}
\hline Sample & \multicolumn{1}{c}{ Contents } \\
Virgin hair & Virgin hair of sample with Tea tree oil $0 \mathrm{~g}$ and perm-base $20 \mathrm{~g}$ \\
$8 \mathrm{~L}(0)$ & Treatment of level-8 sample with Tea tree oil $0 \mathrm{~g}$ and perm-base $20 \mathrm{~g}$ \\
$8 \mathrm{~L}(2)$ & Treatment of level-8 sample with Tea tree oil $2 \mathrm{~g}$ and perm-base $18 \mathrm{~g}$ \\
$8 \mathrm{~L}(4)$ & Treatment of level-8 sample with Tea tree oil $4 \mathrm{~g}$ and perm-base $16 \mathrm{~g}$ \\
$8 \mathrm{~L}(6)$ & Treatment of level-8 sample with Tea tree oil $6 \mathrm{~g}$ and perm-base $14 \mathrm{~g}$ \\
\hline
\end{tabular}


포 전과 후를 비교한 결과 건강모는 증가하고, 8 레벨에서 $0 \mathrm{~g}, 2 \mathrm{~g}, 4$ $\mathrm{g}, 6 \mathrm{~g}$ 함유한 시료의 L 값은 도포 전보다 도포 후의 값이 감소한 것 을 알 수 있었다. 시료 별로 평균의 차이가 표본을 추출 할 때 발생하 는 표본 오차에 의한 차이인지 아니면 모평균 차이에 의한 것이지 판 단하기 위해 모든 시료에 대응표본 $t$-검정을 통해 검정하였다. 건 강모 시료의 도포 전과 후 평균값은 -0.53 차이를 보였고, 유의확률 ( $p$-value) 0.048 로 유의기준 $p<0.05$ 보다 작은 값으로 유의미한 결과 를 알 수 있었다. 이는 귀무가설이 기각되고 연구가설이 채택되어 건 강모에서의 명도 변화가 있는 것을 알 수 있었다. $8 \mathrm{~L}(0)$ 시료의 도포 전과 후의 평균값 차이는 0.20 차이를 보였다. 유의확률은 0.448 로 유의기준 $p<0.05$ 보다 큰 값으로 유의미하지 않음을 알 수 있어 명도 변화는 없음을 알 수 있었다. $8 \mathrm{~L}(2)$ 시료에 도포 전과 후의 평균값은 0.90 차이를 보였다. 검정결과 유의확률이 0.051 로 유의기준 $p<0.05$ 보다 큰 값으로 유의미하지 않음을 알 수 있어 명도 변화는 없는 것을 알 수 있었다. $8 \mathrm{~L}$ (4)시료에 도포 전과 후의 평균값은 차이는 1.00 차이 를 보였다. 검정결과 유의확률이 0.006 으로 유의기준 $p<0.05$ 보다 작 은 값으로 유의미한 결과를 알 수 있어 명도 변화가 있는 것을 알 수 있었다. $8 \mathrm{~L}(6)$ 시료에 도포 전과 후의 평균값은 1.30 차이를 보였다. 검 정결과 유의확률이 0.007 로 유의기준 $p<0.05$ 보다 작은 값으로 유의 미한 결과를 알 수 있어 명도 변화가 있는 것을 알 수 있었다. 8L(2) 시료는 조금의 차이는 있었지만 통계 분석적으로는 차이가 없었고, $8 \mathrm{~L}(4)$ 과 $8 \mathrm{~L}(6)$ 시료는 추출물 함량이 증가함에 따라 명도 변화를 보였 다. 건강모의 명도가 증가한 것은 제형제에 의해 모발 표면의 윤기에 의한 것으로 사료된다. 탈색된 8 레벨의 시료의 명도 감소는 펌베이스
제와 오일을 혼합하여 제조한 제형제로 인해 감소한것으로 사료된다. 이는 오트밀 오일 함량이 증가할수록 $\mathrm{L}^{*}$ 값이 감소한다(Kim, 2020) 는 결과와 같음을 알 수 있었다.

\section{2. 시료 별의 인장강도 측정}

시료 별 도포 전과 도포 후의 인장강도 측정 결과는 Table 4 와 같 다. 티트리 오일을 함유한 개선 제형제로 도포한 모발의 인장강도 평 균은 도포 전과 후를 비교한 결과 건강모와 8 레벨에서 $0 \mathrm{~g}, 2 \mathrm{~g}, 4 \mathrm{~g}$, $6 \mathrm{~g}$ 함유한 시료의 인장강도가 도포 전보다 도포 후의 값이 증가한 것 을 알 수 있었다. 시료 별로 평균의 차이가 표본을 추출 할 때 발생하 는 표본 오차에 의한 차이인지 아니면 모평균 차이에 의한 것이지 판 단하기 위해 모든 시료에 대응표본 $t$-검정을 통해 검정하였다. 건 강모 시료의 도포 전과 후 평균값은 -0.01 차이를 보였다. 유의확률 ( $p$-value) 0.7640 로 유의기준 $p<0.05$ 보다 큰 값으로 유의미하지 않 음을 알 수 있었다. 이는 귀무가설이 채택되고 연구가설이 기각되어 건강모에서의 인장강도 변화가 없는 것을 알 수 있었다. $8 \mathrm{~L}(0)$ 시료 의 도포 전과 후의 평균값 차이는 -0.05 차이를 보였다. 유의확률은 0.489 로 유의기준 $p<0.05$ 보다 큰 값으로 유의미하지 않음을 알 수 있 어 인장강도 변화가 없는 것을 알 수 있었다. $8 \mathrm{~L}(2)$ 시료에 도포 전과 후의 평균값은 -0.19 차이를 보였다. 검정결과 유의확률이 0.123 으 로 유의기준 $p<0.05$ 보다 큰 값으로 유의미하지 않음을 알 수 있어 인 장강도 변화가 없는 것을 알 수 있었다. 8L(4)시료에 도포 전과 후의 평균값은 차이는 -0.20 차이를 보였다. 검정결과 유의확률이 0.023 로 유의기준 $p<0.05$ 보다 작은 값으로 유의미한 결과를 알 수 있어 인장

Table 3. Statistical analysis result value of brightness $L^{*}$

\begin{tabular}{|c|c|c|c|c|c|}
\hline \multirow{2}{*}{ Sample } & & Pre & Post & \multirow{2}{*}{ Statistic } & \multirow{2}{*}{$p$} \\
\hline & & Mean $\pm S D$ & MeanıSD & & \\
\hline Virgin hair & $L^{*}$ & $7.00 \pm 0.47$ & $7.53 \pm 0.50$ & -2.29 & $0.048^{*}$ \\
\hline $8 \mathrm{~L}(0)$ & $\mathrm{L}^{*}$ & $55.9 \pm 0.12$ & $55.7 \pm 0.72$ & 0.794 & 0.448 \\
\hline $8 \mathrm{~L}(2)$ & $\mathrm{L}^{*}$ & $55.9 \pm 0.12$ & $55.0 \pm 0.79$ & 2.25 & 0.051 \\
\hline $8 \mathrm{~L}(4)$ & $\mathrm{L}^{*}$ & $55.9 \pm 0.12$ & $54.9 \pm 0.76$ & 3.54 & $0.006^{*}$ \\
\hline $8 \mathrm{~L}(6)$ & $\mathrm{L}^{*}$ & $55.9 \pm 0.12$ & $54.6 \pm 1.07$ & 3.52 & $0.007^{*}$ \\
\hline
\end{tabular}

${ }^{*} p<0.05$.

Table 4. Statistical analysis result value of tensile strength

(Unit: N)

\begin{tabular}{|c|c|c|c|c|}
\hline \multirow{2}{*}{ Sample } & Pre & Post & \multirow{2}{*}{ Statistic } & \multirow{2}{*}{$p$} \\
\hline & Mean $\pm S D$ & Mean $\pm S D$ & & \\
\hline Virgin hair & $1.96 \pm 0.10$ & $1.97 \pm 0.12$ & -0.32 & 0.764 \\
\hline $8 \mathrm{~L}(0)$ & $1.44 \pm 0.06$ & $1.49 \pm 0.19$ & -0.76 & 0.489 \\
\hline $8 \mathrm{~L}(2)$ & $1.44 \pm 0.06$ & $1.63 \pm 0.18$ & -1.95 & 0.123 \\
\hline $8 \mathrm{~L}(4)$ & $1.44 \pm 0.06$ & $1.64 \pm 0.11$ & -3.59 & $0.023^{*}$ \\
\hline $8 \mathrm{~L}(6)$ & $1.44 \pm 0.06$ & $1.82 \pm 0.17$ & -5.30 & $0.006^{*}$ \\
\hline
\end{tabular}

${ }^{*} p<0.05$. 
강도 변화가 있는 것을 알 수 있었다. 8L(6)시료에 도포 전과 후의 평 균값은 -0.38 차이를 보였다. 검정결과 유의확률이 0.006 으로 유의기 준 $p<0.05$ 보다 작은 값으로 유의미한 결과를 알 수 있어 인장강도 변 화가 있는 것을 알 수 있었다. $8 \mathrm{~L}(2)$ 시료는 조금의 차이는 있었지만 통계 분석적으로는 차이가 없었고, $8 \mathrm{~L}(4)$ 과 $8 \mathrm{~L}(6)$ 시료는 추출물의 함 량이 증가함에 따라 인장강도 변화를 보였다. 이는 인삼추출물의 농 도에 따라 인장강도 차이가 유의하다(Lee \& Han, 2010)는 결과와 같 음을 알 수 있었다.

\section{3. 시료 별의 메틸렌블루를 이용한 흡광도 측정 결과}

시료 별 도포 전과 도포 후의 흡광도 측정 결과는 Table 5 와 같다. 티트리 오일을 함유한 개선 제형제로 도포한 모발의 흡광도 평균은 도포 전과 후를 비교한 결과 건강모와 8레벨에서 $0 \mathrm{~g}, 2 \mathrm{~g}, 4 \mathrm{~g}, 6 \mathrm{~g}$ 함 유한 시료의 흡광도가 도포 전보다 도포 후의 값이 감소한 것을 알 수 있었다. 시료 별로 평균의 차이가 표본을 추출 할 때 발생하는 표본 오차에 의한 차이인지 아니면 모평균 차이에 의한 것이지 판단하기 위해 모든 시료에 대응표본 $t$-검정을 통해 검정하였다. 건강모 시료 에 도포 전과 후 평균값은 0.001 차이를 보였다. 유의확률( $p$-value) 0.604 로 유의기준 $p<0.05$ 보다 큰 값으로 유의하지 않음을 알 수 있 었다. 이는 귀무가설이 채택되고 연구가설이 기각되어 건강모에서는 흡광도 변화가 없는 것을 알 수 있었다. $8 \mathrm{~L}(0)$ 시료의 도포전과 후의 평균 값 차이는 0.001 차이를 보였다. 유의확률은 0.880 로 유의기준 $p<0.05$ 보다 큰 값으로 유의미하지 않음을 알 수 있어 흡광도 변화가 없는 것을 알 수 있었다. $8 \mathrm{~L}(2)$ 시료에 도포 전과 후의 평균값은 0.024
차이를 나타낸다. 검정결과 유의확률이 0.055 로 유의기준 $p<0.05$ 보 다 큰 값으로 유의미하지 않음을 알 수 있어 흡광도 변화가 없는 것을 알 수 있었다. $8 \mathrm{~L}(4)$ 시료에 도포 전과 후의 평균값은 0.034 차이를 보 였다. 검정결과 유의확률이 0.030 으로 유의기준 $p<0.05$ 보다 작은 값 으로 유의미한 결과를 알 수 있어 흡광도 변화가 있는 것을 알 수 있 었다. $8 \mathrm{~L}(6)$ 시료에 도포 전과 후의 평균값은 0.040 차이를 보였다. 검 정결과 유의확률이 0.036 으로 유의기준 $p\langle 0.05$ 보다 작은 값으로 유 의미한 결과를 알 수 있어 흡광도 변화가 있는 것을 알 수 있었다. 통 계분석 결과 시료 $8 \mathrm{~L}(4), 8 \mathrm{~L}(6)$ 이 유의기준이 $p<0.05$ 보다 작은 값으 로 흡광도 변화가 있는 것을 알 수 있어 손상된 모발 개선에 도움이 되는 것을 알 수 있었다. 같은 8 레벨 시료에서는 오일의 함량이 높을 수록 흡광도 차이는 큰 것을 알 수 있어 함량이 높을수록 효과가 큰 것을 알 수 있었다. 흡광도 값이 감소한 이유는 티트리 오일이 탈색으 로 인해 손상된 모피질 내 빈 공간을 채워주고 모발 표면에 흡착된 결 과로 사료된다. 이는 갯지렁이 분해물이 모발 내부에 침투에 모발 밀 도를 높인 것으로 첨가물 함량이 높을수록 감소가 나타났다(Shin \& Kang, 2013)는 결과와 같음을 알 수 있었다.

\section{4. 시료 별의 광택 측정 결과}

시료 별 도포 전과 도포 후의 광택 측정 결과는 Table 6 과 같다. 티트리 오일을 함유한 개선 제형제로 도포한 모발의 광택 평균은 도 포 전과 후를 비교한 결과 건강모와 8 레벨에서 티트리 오일을 $2 \mathrm{~g}$, $4 \mathrm{~g}, 6 \mathrm{~g}$ 함유한 시료의 광택 값이 도포 전보다 도포 후 증가 한 것 을 알 수 있었다. 시료 별로 평균의 차이가 표본을 추출 할 때 발생하

Table 5. Statistical analysis result value of optical density

\begin{tabular}{lccccc}
\hline Sample & Pre & Post & & Statistic & $p$ \\
\cline { 2 - 3 } Virgin hair & Mean \pm SD & Mean \pm SD & & 0.57 & 0.604 \\
8L(0) & $0.056 \pm 0.00$ & $0.055 \pm 0.00$ & 0.16 & 0.880 \\
$8 \mathrm{~L}(2)$ & $0.205 \pm 0.01$ & $0.204 \pm 0.00$ & 3.06 & 0.055 \\
$8 \mathrm{~L}(4)$ & $0.205 \pm 0.01$ & $0.181 \pm 0.01$ & 3.88 & $0.030^{*}$ \\
$8 \mathrm{~L}(6)$ & $0.205 \pm 0.01$ & $0.171 \pm 0.01$ & 3.61 & $0.036^{*}$ \\
\hline
\end{tabular}

${ }^{*} p<0.05$.

Table 6. Statistical analysis result value of gloss meter

(Unit: GU)

\begin{tabular}{lcccc}
\hline Sample & Pre & Post & Statistic & $p$ \\
\cline { 2 - 3 } Virgin hair & Mean \pm SD & Mean \pm SD & & 0.80 \\
8L(0) & $0.65 \pm 0.05$ & $0.67 \pm 0.04$ & 1.00 & 0.343 \\
$8 \mathrm{~L}(2)$ & $2.16 \pm 0.06$ & $2.14 \pm 0.08$ & -4.74 & $0.001^{*}$ \\
$8 \mathrm{~L}(4)$ & $2.16 \pm 0.06$ & $2.26 \pm 0.05$ & -5.50 & $0.001^{*}$ \\
$8 \mathrm{~L}(6)$ & $2.16 \pm 0.06$ & $2.37 \pm 0.08$ & -7.67 & $0.001^{*}$ \\
\hline
\end{tabular}

${ }^{*} p<0.05$. 
는 표본 오차에 의한 차이인지 아니면 모평균 차이에 의한 것이지 판 단하기 위해 모든 시료에 대응표본 $t$-검정을 통해 검정하였다. 건강 모 시료에 도포 전과 후 평균 값은 -0.02 차이를 보였다. 유의확률 ( $p$-value) 0.433 으로 유의기준 $p<0.05$ 보다 큰 값으로 유의하지 않 음을 알 수 있었다. 이는 귀무가설이 채택되고 연구가설이 기각되어 건강모에서는 광택 변화가 없는 것을 알 수 있었다. $8 \mathrm{~L}(0)$ 시료의 도 포 전과 후의 평균 값 차이는 0.02 차이를 보였다. 유의확률은 0.343 으로 유의기준 $p<0.05$ 보다 큰 값으로 유의미하지 않음을 알 수 있 어 광택 변화가 없는 것을 알 수 있었다. $8 \mathrm{~L}(2)$ 시료에 도포 전과 후 의 평균값은 -0.10 차이를 보였다. 검정결과 유의확률이 0.001 로 유 의기준 $p<0.05$ 보다 작은 값으로 유의미한 결과를 알 수 있어 광택 변화가 있는 것을 알 수 있었다. 8L(4)시료에 도포 전과 후의 평균 값은 -0.21 차이를 보였다. 검정결과 유의확률이 0.001 로 유의기준 $p<0.05$ 보다 작은 값으로 유의미한 결과를 알 수 있어 광택 변화가 있 는 것을 알 수 있었다. $8 \mathrm{~L}(6)$ 시료에 도포 전과 후의 평균값은 -0.23 차이를 보였다. 검정결과 유의확률이 0.001 로 유의기준 $\mathrm{p}<0.05$ 보다 작은 값으로 유의미한 결과를 알 수 있어 광택 변화가 있는 것을 알 수 있었다. 통계 결과 $8 \mathrm{~L}(2), 8 \mathrm{~L}(4), 8 \mathrm{~L}(6)$ 모든 시료에서 도포 후의 광택이 증가하여 티트리 오일에 의한 광택 변화가 있는 것을 알 수 있 었다. 이는 모발 개선을 위해 transglutaminase 사용하였을 때 윤기 가 증가하였다(Kim \& Park, 2013)는 결과와 같음을 알 수 있었다.

\section{Conclusion}

본 연구는 손상된 모발의 개선 정도를 알기 위해 티트리 오일 성분 으로 제조한 제형제로 손상된 모발에 도포 전과 도포 후의 차이가 있 어 개선 효과가 있는지를 연구하였다. 모질 개선 효과를 알 기 위해 티트리 오일을 $0 \mathrm{~g}, 2 \mathrm{~g}, 4 \mathrm{~g}, 6 \mathrm{~g}$ 으로 함량을 다르게 하여 모질 개선 제형제를 제조하여 사용하였다. 시료 별 $\mathrm{L}^{*}$ 을 측정하여 티트리 오일 에 의한 명도 변화를 비교 분석하였고, 손상된 모발 개선 효과를 알 기 위해 모발 인장강도, 메틸렌블루를 이용한 흡광도, 광태 측정을 하였다. 그 결과 다음과 같은 결론을 얻었다.

첫째, 시료 별 명도 변화를 알기 위한 L* 값 측정 결과 평균값은 건 강모는 증가하고 8레벨의 값은 도포 후 감소하였다. 통계분석 결과 건강모와, $8 \mathrm{~L}(4), 8 \mathrm{~L}(6)$ 시료는 유의미한 결과로 모발을 밝게 하는 것 을 알 수 있었다.

둘째, 인장강도 측정 결과 시료 별의 인장강도 측정결과 평균값은 건강모와레벨에서 $0 \mathrm{~g}, 2 \mathrm{~g}, 4 \mathrm{~g}, 6 \mathrm{~g}$ 함유한 시료의 인장강도가 도 포 전보다 도포 후의 값이 증가한 것을 알 수 있었다. 통계분석 결과 $8 \mathrm{~L}(4), 8 \mathrm{~L}(6)$ 시료는 유의미한 결과로 모발의 인장강도가 증가하여 개 선효과가 있는 것을 알 수 있었다.

셋째, 메틸렌블루를 이용한 흡광도 측정 결과 평균값은 건강모와
8레벨에서 $0 \mathrm{~g}, 2 \mathrm{~g}, 4 \mathrm{~g}, 6 \mathrm{~g}$ 함유한 시료의 흡광도가 도포 전보다 도 포 후의 값이 감소한 것을 알 수 있었다. 통계분석 결과 $8 \mathrm{~L}(4), 8 \mathrm{~L}(6)$ 시료는 유의미한 결과로 모발의 흡광도가 감소하여 개선효과가 있는 것을 알 수 있었다.

넷째, 광택 측정 결과 평균값은 건강모와 8레벨에서 티트리 오일 을 $2 \mathrm{~g}, 4 \mathrm{~g}, 6 \mathrm{~g}$ 함유한 시료의 광택 값이 도포 전보다 도포 후 증가 한 것을 알 수 있었다. 동계분석결과 $8 \mathrm{~L}(2), 8 \mathrm{~L}(4), 8 \mathrm{~L}(6)$ 시료에서 도포 후의 광택이 증가하여 티트리 오일에 의한 광택 변화가 있는 것 을 알 수 있었다.

이와 같은 결과로 천연 티트리 오일이 함유된 제형제가 손상된 모 발에 모질 개선효과가 있는지 연구한 결과 오일 함량을 $4 \mathrm{~g}$ 이상 함 유하여 도포 한 시료에 차이가 있음을 알 수 있어 손상 모발 개선 효 과가 있는 것을 알 수 있었다. 손상된 모발 상태를 최적의 모발 상태 로 유지 관리 하기 위한 방법으로 다양한 연구가 이루어지고 있지만 여전히 미비한 실정이다. 차후 다양한 종류의 오일류, 천연 추출물에 의한 모발 개선 효과 연구가 필요하고, 실험 측정 방법과, 처치 방법 의 다양화가 필요하다.

\section{Author's contribution}

JSK designed all experimental investigations, and collected tea tree oil data and wrote the manuscript.

\section{Author details}

Ju-Sub Kim (Professor), Department of Beauty Design, Sangji University, 84 Sangjidae-gil, Wonju-si, Gangwondo 26339, Korea.

\section{References}

Bae MG. A study on the effect of antioxidant activities and skin wrinkling improvement of tea tree essential oil. Journal of Beauty Industry, 14: 67-81, 2020.

Jang KO, Choi JS. Morphological change of hair by the treatment of coloring. Journal of the Korean Society of Cosmetology, 7: 21-28, 2001.

Jung HH, Shin MK, Lee SY, Lee SR, Kim MS. Effect of extract from fermented black soybean (Glycine max var. Seoritae) on the hair damaged by decolorization. Journal of the Society of Cosmetic Scientists of Korea, 43: 149-155, 2017.

Kim HG, Cheong MS. A study on hair care. Asia-pacific Journal of Multimedia Services Convergent with Art, Humanities, 
and Sociology, 8: 827-835, 2018.

Kim HK. Development of an after-treatment agent, using an alkaline hair treatment. Journal of Digital Convergence, 15: 509-517, 2017.

Kim JH. Chemical and mechanical improvement of damaged hair treated with Cordyceps militaris extract. Korean Society for Biotechnology and Bioengineering Journal, 28: 191-195, 2013.

Kim JS, Kim CS, Lim DJ, Choi EJ, Jang HE, Shin JE. Scalp \& hair management. Kuhminsa, Seoul, pp31-32, 2010a.

Kim JS, Kim CS, Kim YJ, You SE. Hair science. Hunminsa, Seoul, pp68-69, 2010b.

Kim JS, Shin HC, Kim GH. Hair cosmetics materials, Kuhminsa, Seoul, p149, 2017.

Kim JS. Effect of oatmeal oil on hair texture improvement. Asian Journal of Beauty and Cosmetology, 18: 599-608, 2020.

Kim JS. Effect of peanut oil on hair yexture improvement. Asian Journal of Beauty and Cosmetology, 18: 331-340, 2020a.

Kim JS. Effect of purple sweet potato on hair dyeing and hair texture improvement. Asian Journal of Beauty and Cosmetology, 18: 321-330, 2020b.

Kim MS, Han JS. A study of effect of natural extract on improvement of hair damage. Journal of the Korean Society of Beauty and Arts, 14: 249-262, 2013.

Kim SH, Lee SY, Li SH. The effect of essential oils from tea-tree and palmarosa on the acne skin. Asian Journal of Beauty and Cosmetology, 38: 1083-1090, 2013.

Kim YS, Park SJ. Application of transglutaminase for hair revitalization. Journal of the Society of Cosmetic Scientists of Korea, 39: 25-30, 2013.

La CS, Kweon SA, Park Y. Changes of wave formation and damage degree in permanent wave hair according to UVB irradiation time. Journal of Investigative of Cosmetology, 9: 413-423, 2013.

Lee HN, Han MY. Hair damage rates and morphological changes from application of a reducing agent prescribing ginseng. Asian Journal of Beauty and Cosmetology, 8: 211-223, 2010.

Lim BT, Seo HA, Song SH, Son SK, Kang NG. A study for perception of hair damage using friction coefficient of human hair. Journal of the Society of Cosmetic Scientists of Korea, 46: 295-305, 2020.

Min MJ, Na MS, Ryu EM. Gray mullet extract on physical damage of colored and bleached hair. Asian Journal of Beauty and Cosmetology, 9: 1-9, 2011.

Park GM, Park SY, Kim BK. A study on the effect of polypeptide and water-soluble silicon on hair discoloration. Journal of Health and Beauty, 13: 45-52, 2019.

Shin JE, Kang SM. Pretreatment effect of different molecular weight lugworm protein hydrolyzate in treating permanent wave of virgin hair. Asian Journal of Beauty and Cosmetology, 11: 43-50, 2013.

Song PY, Leem MH, Choe TB, Lee SS. The study of hair damage measurement \& mechanical properties by chemical treatment. Asian Journal of Beauty and Cosmetology, 4: 105-112, 2006. 


\section{국문초록}

\section{티트리 오일의 손상모발 개선효과}

김주섭

상지대학교 뷰티디자인학과, 강원도 원주시, 한국

목적: 본 연구는 티트리 오일로 손상된 모발에 도포하여 개선 효과를 알아보고자 하였다. 방법: 티트리 오일 함량을 $0 \mathrm{~g}, 2 \mathrm{~g} 6 \mathrm{~g}, 6$ $\mathrm{g}$ 으로 각각 모질 개선 제형제를 제조하였다. 제조한 제형제로 8 레벨로 탈색한 시료 모발에 도포 전과 후를 측정하여 비교 분석하였 다. 모발의 명도 변화를 알기 위해 색차계를 이용하여 $\mathrm{L}^{*}$ 값을 측정하였다. 또한 손상된 모발 개선 효과를 알기 위해 모발의 인장강 도, 메틸렌블루를 이용한 흡광도, 광택을 측정하였다. 결과: 시료 별 평균값 $\mathrm{L}^{*}$ 값은 건강모는 증가, 8 레벨 시료는 감소하였다. 통 계 결과 건강모와, $8 \mathrm{~L}(4), 8 \mathrm{~L}(6)$ 시료는 유의미한 결과를 보였다. 인장강도 측정결과 평균값은 건강모와 8레벨 시료 모두 도포 후 증 가하였다. 통계 결과 $8 \mathrm{~L}(4), 8 \mathrm{~L}(6)$ 시료는 유의미한 결과를 보였다. 흡광도 측정결과 평균값은 건강모와 8레벨 시료 모두 도포 후의 값이 감소하였다. 광택 측정결과 평균값은 티트리 오일을 함유한 제형제로 도포한 모든 시료의 값이 증가하였다. 통계 결과 8L(2), 8L(4), 8L(6) 시료에서 도포 후의 값이 증가하였다. 결론: 티트리 오일이 손상된 모발에 모질 개선 효과가 있는 것을 알 수 있었다. 차후 다양한 오일류, 천연 추출물에 의한 손상 모발 개선 효과 연구가 필요하다.

핵심어: 티트리 오일, 모발, 개선, 모질, 손상

\section{참고문헌}

김민선, 한진섭. 천연 추출물의 손상모발 개선효과에 관한 연구. 한국인체미용예술학회지, 14: 249-262, 2013. 김선희. 이선영, 리순화. 티트리 및 팔마로사 에센셜 오일의 여드름 피부에 미치는 효과. 아시안뷰티화장품학술지, 11: 1083-1090, 2013.

김윤석, 박수진. 모발 개선을 위한 Transglutaminase의 적용. 대한화장품학회지, 39: 25-30, 2013. 김정화. 동충하초 추출물에 의한 모발의 화학적·물리적 개선효과. KSBB Journal, 28:191-195, 2013 김주섭, 김찬수, 임대진, 최은정, 장현희, 신지은. 두피모발관리학. 구민사, 서울, pp31-32, 2010a. 김주섭, 김찬수, 김유정, 유세은. 모발과학. 훈민사, 서울, pp68-69, $2010 \mathrm{~b}$. 김주섭, 신홍철, 김건희. 모발 화장품 성분학. 구민사, 서울, $\mathrm{p} 149,2017$. 김주섭. 오트밀 오일의 모질 개선 효과. 아시안뷰티화장품학술지. 18: 599-608, 2020. 김주섭. 땅콩오일의 모질개선효과. 아시안뷰티화장품학술지, 18: 331-340, 2020a. 김주섭. 자색고구마의 염색효과와 모질 개선효과 연구. 아시안뷰티화장품학술지, 18: 321-330, 2020b. 김형겸, 정미숙. 모발 관리에 대한 고찰. 예술인문사회 융합 멀티미디어 논문지, 8: 827-835, 2018. 김혜균. 알칼리성 모발처리제를 이용한 후처리제 개발. 디지털융복합연구, 15: 509-517, 2017. 라채숙, 권수애, 박용. 자외선 조사 시간에 따른 퍼머넌트 웨이브 모발의 웨이브 형성도와 손상도 변화. 대한미용학회지, 9: 413-423, 2013.

민명자, 나명순, 류은미, 차월석. 숭어추출물이 염색과 탈색 모발의 물리적 손상에 미치는 영향. 아시안뷰티화장품학술지, 9: 1-9, 2011.

박가미, 박선이, 김병관. Polypeptide와 수용성 규소가 모발 손상도에 미치는 영향. 국제보건미용학회지, 13: 45-52, 2019.

배민규. 티트리 에센셜 오일의 항산화 활성 및 피부 주름개선 효과. 뷰티산업연구, 14: 67-81, 2020. 신지은, 강상모. 정상모의 퍼머넌트 웨이브 시술 시 분자량 분포도가 다른 갯지렁이(Marphysa sanguinea) 단백질 분해물 
의 전처리 효과. 아시안뷰티화장품학술지. $11: 43-50,2013$.

송팔용, 임미혜, 최태부, 이승선. 모발의 화학적 처리에 의한 손상도 측정 및 기계적 특성에 대한 연구. 아시안뷰티화장품 학술지, 4: 105-112, 2006.

이하나, 함미영. 인삼 추출물을 처방한 환원제 적용에 따른 모발 손상도 및 형태학적 변화. 아시안뷰티화장품학술지, 8: 211-223, 2010.

임병택, 서홍안, 송상훈, 손성길, 강내규. 모발의 마찰계수를 통한 모발 손상 인식 연구. 대한화장품학회지, $46: 295-$ $305,2020$.

장경옥, 최정숙. 칼라링 처리에 의한 모발의 형태학적 변화. 한국미용학회지, 7: 21-28, 2001.

정희훈, 신민규, 이수열, 이상린, 김무성. 서리태 발효추출물이 탈색을 통해 손상된 모발에 미치는 영향. 대한화장품학회 지, 43: 149-155, 2017. 


\section{中文摘要}

\section{茶树油改善头发损伤的作用}

金周焂

尚志大学美容学科, 江原道原州市, 韩国

目的: 研究茶树油对受损头发的影响。方法: 在头发上添加不同剂量的茶树油（0、2、4和6 g) , 制成质地改善 剂。对漂白至8级的头发样本，在使用前和使用后，通过测量该药剂的效果进行对比分析。为了检查头发亮度的 变化, 使用色差计测量L“值。此外, 为了确定该制剂对受损头发的影响, 该研究测量了拉伸强度、亚甲基蓝的吸 光度和头发光泽。结果: 健康头发的平均 L“值增加, 但 $8 L$ 样本的平均 L'值减少。分析表明, 健康的头发、 $8 \mathrm{~L}$ (4) 样本和8L（6）样本显示了统计意义的显著结果。应用茶树油后, 健康和8L头发样本的拉伸强度平均值均增加。 统计结果, $8 \mathrm{~L}$ （4）和8L（6）样本显示出统计意义的显著结果。在吸光度方面, 健康和 $8 \mathrm{~L}$ 头发样本在使用后的 平均值均下降。此外, 使用含有茶树油的试剂的样品的头发光泽值增加。统计结果显示, 8L（2）、8L（4）和8L （6）样品在施用茶树油后,其值增加。结论：结果证实了茶树油对受损头发在拉伸强度、吸光度和光泽方面具有 改善作用。该研究建议, 为了改善头发的其他特征和使用更多的样本, 有必要进一步研究各种油和天然提取物 对受损头发的作用。

关键词: 茶树油，头发，改善，头发质地，损伤 